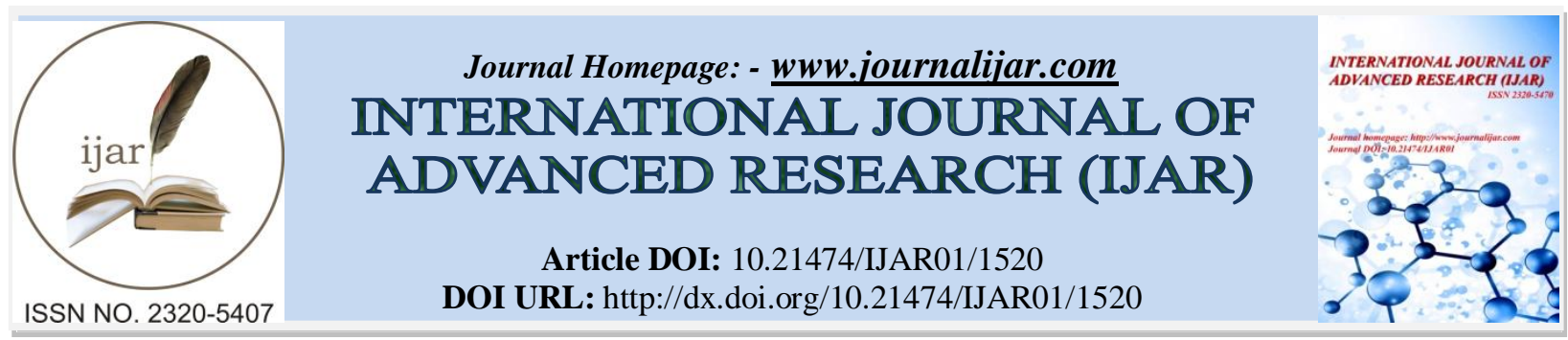

RESEARCH ARTICLE

\title{
A STUDY OF ADJUSTMENT OF ORPHANAGE-REARED STUDENTS AND FAMILY-REARED STUDENTS.
}

Caroline Beck ${ }^{1}$ and Prof. Usha Mishra ${ }^{2}$.

1. D.Phil. Research Scholar, (UGC SRF), Department of Education, University of Allahabad, Allahabad.

2. Professor, Department of Education, University of Allahabad, Allahabad.

\section{Manuscript Info}

\section{Manuscript History}

Received: 16 July 2016

Final Accepted: 10 August 2016

Published: September 2016

\section{Key words:-}

Orphanage-reared students, familyreared students, emotional, social and educational adjustment.

\section{Abstract}

The objective of this study was to make comparison between orphanage-reared students and family-reared students on Adjustment. The Adjustment considered here were emotional, social and educational. A sample of 102 orphanage-reared students and 102 family-reared students studying with them in classes $6^{\text {th }}$ to $8^{\text {th }}$ standard were taken from three KAVAL towns (Allahabad, Varanasi and Lucknow.) of Uttar Pradesh. The data was collected using Adjustment Inventory for school children by Sinha and Singh. The study indicates that there was significant difference between orphanage-reared students and family-reared students on these Adjustment types. (Emotional, social and educational)

Copy Right, IJAR, 2016,. All rights reserved.

\section{Introduction:-}

Life is a process of progressive adjustment and children should be stimulated to do their best. In the contemporary view a child is seen as a helpless being neither good nor bad at birth, one who has to be protected and moulded through discipline. Children therefore, need to be cherished, nurtured and developed with tender care, as their behaviour, adjustment, intellectual development, emotional security, self esteem and social attitudes are greatly influenced by the way that they are brought up. It is ultimately the parents' responsibility to see that as the child grows up, as he/she is being able to discriminate good from evil, constantly adopting the former and eschewing the latter. If proper care is given to children during their formative years, it will help them to learn and respond appropriately to life situations. Warm and affectionate parents who employ cooperative and democratic means to develop guidelines, provide for their children a laboratory for the practice of autonomy (Schaefer, 1959).The children are also resourceful, cooperative, self-reliant, well adjusted in social situations and they develop a sense of responsibility and discharge their task with assurance and efficiency(Kuppuswamy,1984).The significance of studying depend on their parents to acquire happiness which is a foundation of security. Children from democratic family are active, fearless and outgoing in both friendly and hostile ways.

They possess leadership qualities, intellectual curiosity, constructiveness and are highly active and demanding (Baldwin, 1948), whereas children reared in autocratic homes are unpopular with associates, quarrelsome, emotionally quarrelsome, emotionally unstable, more sensitive to praise and blame and less considerate of others. Poor parent-child relationship produce devastating effect on the child relationship produce devastating effects on the child, which is tough to erase, even at later stage.

Corresponding Author:- Caroline Beck.

Address:- D.Phil. Research Scholar, (UGC- SRF), Department of Education, University of Allahabad, 


\section{Adjustment:-}

All people have psychological and physical needs which constantly or intermittently require satisfaction. The process by which they overcome obstacles to satisfy these needs is termed as the adjustment process. It is through the process of adjustment that people establish and maintain a satisfactory relationship to the physical world around them and to other people, to the culture at large and to themselves. Adjustment is that relationship which exists between an individual and his environment especially his social environment in the satisfaction of his needs.

\section{Objective:-}

- To study the adjustment (emotional, social and educational) of orphanage reared students and family reared students.

\section{Hypotheses:-}

- There is no significant difference in emotional adjustment between the orphanage reared students and family reared students.

- There is no significant difference in social adjustment between the orphanage reared students and family reared students.

- There is no significant difference in educational adjustment between the orphanage reared students and family reared students.

\section{Sample:-}

Purposive sampling method was used to select 100 orphanage-reared students and 100 family-reared students studying with them in classes $6^{\text {th }}$ to $8^{\text {th }}$ standard from three cities (Allahabad, Varanasi and Lucknow) of Uttar Pradesh.

\section{Description of Tools:-}

Adjustment inventory for school students:-

The Adjustment Inventory has been designed for use with Hindi knowing school students (age group 14 to 18 years) of India. The inventory seeks to segregate well adjusted secondary students in the three areas of adjustment: Emotional, Social and Educational. Coefficient of reliability was determined by split-half method, Test retest method and K-R formula-20and came out to be $0.95,0.93$ and 0.94 respectively.

In item analysis validity coefficients were determined for each item by biserial correlation with both the criteria i) total score and ii) area score, significant level being .001. Percentile norms were computed for males and females of all the three areas (Emotional, Social and Educational) of adjustment separately as also for the whole inventory. Means and standard deviations of the population upon which norms are based. For any answer indicative of adjustment zero is given, otherwise a score of one is awarded. The inventory is designed to be aid in counseling school students of age group 14-18 years whose personal problems pertain to any of the three areas included in the test. The use of Deonagari letters A, B, and C corresponding to Emotional adjustment, Social adjustment and Educational adjustment enables the test user to discover readily questions relating to each measure. The total score indicates the general adjustment status.

\section{Result:-}

\section{Analysis and interpretation:-}

The obtained data was subjected to necessary statistical computation. The data was mainly interpreted in terms of mean. T-ratio was used to find out significant difference.

It was hypothesized that there is no significant difference in the adjustment between the orphanage-reared students and family-reared students. To test this hypothesis mean, standard deviation and t-test were calculated separately for the three areas of adjustment and reported in the table. 
Table 5.03:- Comparison between orphanage-reared students and family-reared students on Adjustment.

\begin{tabular}{|l|l|l|l|l|l|l|}
\hline \multirow{2}{*}{ S.No. } & Variable & \multicolumn{2}{|l|}{ Orphanage-reared students } & \multicolumn{2}{l|}{ Family-reared students } & T-ratio \\
\cline { 3 - 7 } & & N=102 & N=102 & \\
\hline & & Mean & $\begin{array}{l}\text { Standard } \\
\text { Deviation }\end{array}$ & Mean & $\begin{array}{l}\text { Standard } \\
\text { Deviation }\end{array}$ & \\
\hline $\mathbf{1 .}$ & $\begin{array}{l}\text { Emotional } \\
\text { Adjustment }\end{array}$ & 4.6381 & 4.13736 & 1.7549 & 1.7549 & $6.664^{* *}$ \\
\hline $\mathbf{2 .}$ & $\begin{array}{l}\text { Social } \\
\text { Adjustment }\end{array}$ & 2.9412 & 1.80112 & 8.1333 & 2.62776 & $16.535^{* *}$ \\
\hline $\mathbf{3 .}$ & $\begin{array}{l}\text { Educational } \\
\text { Adjustment }\end{array}$ & 5.0952 & 3.54510 & 2.5294 & 1.59023 & $6.685^{* *}$ \\
\hline
\end{tabular}

**Significant at .01 level

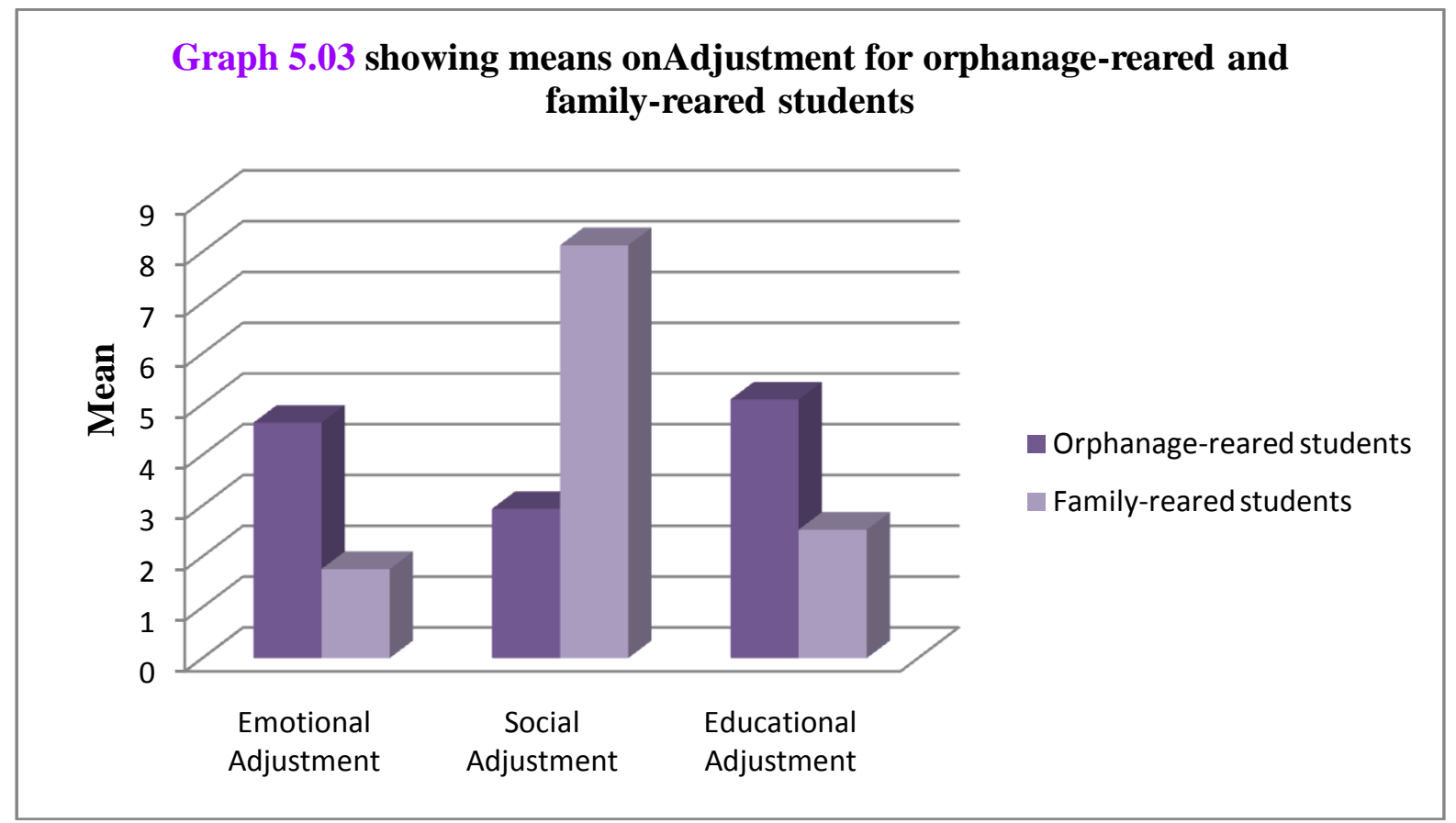

From the observation of the table 5.03 it is evident that t-ratios are significant for emotional, social and educational adjustment since the obtained $\mathrm{t}$-value is more than the table value at .01 level. $(\mathrm{p}<.01, \mathrm{df}=117)$. So, it can be inferred that orphanage-reared students and family-reared students differ from one another for these adjustment types. According to the norms of the test it can be interpreted that orphanage-reared students have scored more for emotional adjustment and educational adjustment than family-reared students. They have scored less for social adjustment than family-reared students., which means that orphanage-reared students are less emotionally, socially and educationally stable than family-reared students. The reason behind this is that children from deficient environment is unable to satisfy the needs of food, shelter and clothing, there is lack of opportunities for social contacts because of geographic isolation and unfavourable social attitudes, the need of security,belongingness, acceptance,love,identification and approval are not fulfilled. A feeling of alienation, fear from challenges, a desire to cling to familiar ,many feelings of guilt and shame, limited trust in adults, tendency to respond with trigger-like reactions, having low standard of conduct, negative attitude towards school, teachers and free use of violence (Krogman,1956).lack of order in general life and orientation to the environment and better desire for living.(Parker1968 andRiessman1962). The findings of the study support the findings of Bossio 1965, Youngleson1973,Ushashree 1980, Nagar1985,Zaidi 1986and Manral1988 who determined that maladjustment was revealed by deprived children which affected their intellectual, emotional and social development. 


\section{Findings of the study:-}

There was difference in three areas of adjustment between orphanage-reared students and family-reared students. Orphanage-reared students were found to have less emotional and educational adjustment than family-reared students. Family-reared students have better social adjustment than orphanage-reared students.

\section{Conclusion:-}

Orphans deviate significantly from the normal ones, such children are exceptionally inferior or superior to the normal children in terms of physical development, mental ability, social behaviour and emotional reactions that they experience a sort of maladjustment in life and face difficulties in making a successful adjustment to people and situation.

Healthy interests, sound attitudes and balanced hierarchy of values will enable the orphans for proper selfunderstanding and this together will pave the way for health, happiness, efficiency and success.

\section{References:-}

1. Bossio, V. (1965): Early Prolonged Separation and Emotional maladjustment. In Pringle, M.L.K. Deprivation and Education, London, Longmans, Green and Company Limited. pp. 65-95

2. Krogman, J. (1956): Cultural Deprivation and Child Development, High Points, 38.

3. Sinha, A.K.P.and Singh, R.P. Adjustment Inventory for school students National Psychological Co-operation. Bhargava Bhawan, 4/230, Kachari Ghat, Agra-282004

4. Singh Chandra Hans (1986): Problems and adjustment patterns of Children living in destitute homes in Uttar Pradesh. Ph.D.Thesis Banaras Hindu University.

5. Riessman, F. (1962): The Culturally Deprived Child. New York, Harper and Row Publishers.

6. Ushashree (1980): Social disadvantage, academic adjustment and scholastic Achievement, Social Change, 10, pp.23-30.

7. Youngleson M.L. (1973): The need off Affiliate and Self-esteem in Institutionalized Children Journal of personality and social psychology Vol.26, No.2, pp.280-286.

8. Zaidi, R. (1986): Effect of Parental Deprivation and some socio-Psychological factors on the Scholastic achievement of Primary school children.D.Phil, Education, Allahabad University, Allahabad.

9. Nagar (1985): A study of socio-psychological problems and personality patterns of Deprived children living in Destitute homes of Rajasthan, Ph.D.Education, M.Sukh University (1985).Quoted in M.B.Buch (Ed.) Fifth Survey of Educational Research, NCERT.New Delhi, Vol.2, p.172.

10. Manral, B. (1988): The impact of emotional maturity and prolonged deprivation on disciplined behaviour among university students in relation to their academic Achievement Ph.D.Education, Kumaun University. Quoted in M.B.Buch (ed.)Fifth Survey of Educational Research,(1985) NCERT,New Delhi.

11. Parker (1968): Science Activities In Tiedt S.W. (Ed.): Teaching the Disadvantaged Child, New York, oxford University Press. 